\title{
John Locke’s A Letter Concerning Toleration: Lessons for the Nigerian Religious Environment
}

\author{
Gabriel Bubu Ncha, Oduora Okpokam Asuo, Michael Ukah \\ University of Agriculture
}

\begin{abstract}
Religious convictions are a source of bitter confrontations between especially the Muslims and Christians of Nigeria. The problem is so endemic that there are conspicuous spillovers into the political and social spheres of everyday living in the country. This reality threatens the already fragile unity and social health of the country and hence becomes one that needs special attention. The need to proffer solution to this cankerworm demands that we take a historical survey of similar or near-similar situations in the human civilization and excavate ideas that were given as a way forward. It is in this bid that the ideas of John Locke in his book A Letter Concerning Toleration become very useful. Locke argued for a secular state with a clear dichotomy between government activities, which belong to the public domain and hence involve every citizen and matters of faith which are private and devoid of any form of coercion. Such differentiation is meant to remove the force of compulsion from religion and the practice thereof as well as keep the government "undefiled" when the need for adjudication in matters that pertain to religion eventually arises. Locke's ideas in the book were aimed at forging peace and decorum in an English society that was virtually turned asunder by the demon of religious intolerance. This scenario exactly qualifies present-day Nigeria, hence there is much need to $\mathrm{x}$-ray these ideas and apply same in our desire to nip the menace of religious bigotry in the bud. The nature of this work made it necessary to apply the method of text analysis and evaluation to enable us to get an adequate appreciation of Locke's intentions and how these can serve our purpose in present-day Nigeria.
\end{abstract}

Keywords: toleration, religion, secular, faith, bigotry

\section{Introduction}

Nigeria is a multi-ethnic and multi-religious embodiment. The major religious affiliations have however become thinned to two- Islam and Christianity. The assertive nature of these two may be responsible for their ability to take over the religious scene in Nigeria and send others, like African traditional religion, to the background. The architects of Nigeria may not have given much thought to the influence that the religious inclinations of the Nigerian people can have on the overall development of the country and the coexistence of the component units. The attitude of the colonialists is not unconnected with their ignorance of the discovery of John Mbiti that the average African is notoriously religious and organizes his society within and around his

Gabriel Bubu Ncha, Ph.D., Department of Philosophy, University of Calabar, Nigeria; main research field: Ethics and Logic.

Oduora Okpokam Asuo, Ph.D., Department of Philosophy, University of Calabar, Nigeria; main research field: Social and Political Philosophy, Environmental Philosophy, Philosophy of Science.

Michael Ukah, Ph.D., Professor, Department of General Studies, University of Agriculture, Umudike, Nigeria; main research field: Social and Political Philosophy and Ethics. 
religious convictions $(1997,1)$. As he puts it, “Africans are notoriously religious, and each people has its own religious system with a set of beliefs and practices. Religion permeates into all the departments of life so fully that it is not easy or possible to isolate it” (1). The notoriety that Mbiti talks about is easily seen in the social and political structure of the Nigerian state. It is often the case that religious sentiments are made to take the place of national interest and excellence amongst people in Nigeria. This has greatly hampered proper growth and development of the country.

While avoiding the temptation of looking at Mbiti's assertion from a purely negative perspective, it is apt to mention that religion and the practice thereof is not entirely negative or anti-developmental as current events in Nigeria have forced people to believe. On the contrary, man's encounter with and worship of God is one of those qualities that designate him as being a higher being. The emotional, psychological, and social stability of men and their ability to cohere peacefully owe a lot to their relationship to the Divine. However, religion is like a two edged sword-it cuts either ways. While creating social cohesion and harmony in some places, it is also causing division and bloodshed in others. It all depends on what use men want to put it to. Religion is only a servant of mankind and hence serves only the purpose(s) to which they put it. It is quite unfortunate that the case with Nigeria has a lot to do with the negative designation of religion.

One of the major problems in Nigeria today is the insurmountable desire of religious bodies and sects to push it down, the consciousness of others that they have supremacy over them. These acts and the repulsion thereof are the cause of countless religious riots, muggings, carnages, and outright wars. The Maitatsine Riots, the Kaduna Riots, and the ongoing Boko Haram mayhem are a few of the troubles that are sponsored by religious misgivings in Nigeria.

The economic importance of these crises cannot be quantified. Most import and export routes are affected by these crises. For instance, most Nigerian borders in the North eastern part of the country are sealed to prevent the importation of militants from nearby countries to join the war. Businesses within the areas really affected by the crises have no option but to shut down. This brings untold hardship to the people of the area. Schools have also been forced to close down indefinitely thereby slowing down the pace of growth and development of these areas. All of these points to the evil that follows the crises are products of religious intolerance wherever they may occur in the world.

It is far from the truth that Nigeria is the only country on earth that is plagued by religious quagmires nor is it true that religious crises of this or higher dimensions have never occurred in history. Such religious conflicts as the Hussite Wars within the Catholic Church and the Holy Roman Empire in Bohemia between 1419 and 1436; religious wars in Ireland and England; the Arab- Israeli conflict and countless other wars that were sparked by religious disagreements are cases that can be readily sieved from the archives of history. In the course of history also, it is the case that some of these conflicts were resolved because reason and good arguments were allowed to prevail over and above mere religious sentiments.

Speaking of reason and good judgment brings us to the point that one of the greatest sponsors of religious crises is ignorance and emotional manipulation of unsuspecting members of society. During the Crusades of 1095-1291 which witnessed brutality and inhumanity in large scale, the key actors were drawn by ignorance and emotional manipulation by their leaders. Bernard of Clairvaux (1090-1153), a Western Christian mystic, developed a theology that life's highest and most honorable calling is to be a warrior-priest (Caner \& Caner 2002, 74). This manipulation, coupled with the ignorance of the ordinary Christians of his day about the bible's stance on such matters, sparked an increase in the number of men that were ready to lay down their lives "for 
God.” Similar manipulations were rife in the 18th century England of John Locke and this is the main cause of the problem in present-day Nigeria.

John Locke used his book, A Letter Concerning Toleration, to bring religious bigotry and bigots to the court of reason. He was of the opinion that religion is purely a faith-based affair and needs conviction rather than compulsion. Therefore, people should be free to choose to be Mohammedans, Christians, or whatever else that satisfies their spiritual aspirations. In the book, Locke was particular about sects within the Christian faith since the religious tension of his age was mostly between Catholics and Protestants. Nigeria's case is a bit different from that of the England of Locke because then Christianity was the predominant religion of England and had little or no competition from any other religious faith whereas the religious crises in Nigeria involve more than one religions.

In spite of this however, the bitterness and division observed in the sectarian divisions that trailed religious intolerance in Locke's book are nothing different from those observed in the Nigerian religious environment. Apart from Nigeria, it is observed in places like Iraq and Afghanistan that Muslims of different sects could be engaged in violence that is worse than the one between different religions. It is because of this that we think that Locke's exposition will highlight Nigeria's religious problems and proffer solutions that can help engender a more convivial and tranquil religious environment in Nigeria. Locke's ideas were conveyed in a book and the intention was to give his fellow English men the opportunity to be properly educated or re-educated to accept other people's faiths and personalities without unnecessary misgivings. This highlights the need for proper civic education especially as it concerns tolerance for contrary intellectual and religious opinions in Nigeria. This paper aims at providing such a means in a country that has often experienced unrest occasioned by religious intolerance.

\section{The Concept of Religious Intolerance}

Religion is often defined as faith or belief in a being other than oneself which deserves to be worshiped. It is "the belief in the existence of a god or gods, and the activities that are connected with the worship of them" (Oxford Advanced Dictionary). Religions may be monotheistic or polytheistic depending on the number of gods that they acknowledge. Religion plays a very pivotal role in people's lives to the extent that rights to religious freedom are seen as both inalienable and fundamental.

According to the Watch Tower Bible and Tract Society, "with so many religions in a world that gets smaller and smaller by virtue of ever faster travel and communication, the impact of various faiths is felt worldwide whether we like it or not” (Mankind's Search for God, 1990, 7). With this, reality comes the need to know and learn to live with the faiths of others which may be different from one's own. As it is put in the book quoted above, knowledge of other religions leads to understanding, and understanding to tolerance of people with a different viewpoint (8). This point is particularly noteworthy because the religious crises that threaten the very existence of the Nigerian nation spring from and are sustained by ignorance and miseducation about other religions and how to cohere with people with different opinions from ours.

According to the Wikipedia, the mere statement on the part of a religion that its own beliefs and practices are correct and any contrary beliefs are incorrect does not in itself constitute intolerance, religious intolerance, rather, is when a group (e.g., a society, religious group, non-religious group) specifically refuses to tolerate practices, persons or beliefs on religious grounds (Intolerance, n.p.). This refusal to tolerate the practices, persons, and beliefs of others is practical intolerance as opposed to mere ideological disagreements regarding 
religious beliefs and world-views. Doctrines of religious toleration aim at pointing out the flaws inherent in the practical lack of toleration for the religious positions of others while at the same time showing the benefits that can be reaped from understanding and accommodating the views and practices of persons and religious beliefs outside one’s domain.

\section{Causes of Religious Intolerance}

Conflicts in the world often take either a political, economic or an ethno-religious dimension. Asuo and Ekpenyong held that the religious conflicts often take the form of assassinations, sabotage, armed struggles, riots, kidnaps, war and secession (86). Religious conflicts are products of religious intolerance and diverse factors are responsible for religious intolerance. Some of these include:

(1) Manipulation: Human beings are emotional beings and most of the actions and reactions of men stem from this nature. If emotivist ethics is anything to go by, then our actions will be far from being results of rational summations but mere emotional responses to situations (Holmes 2007, 26). With this nature, man becomes a being that easily falls prey to emotional sentiments of which religion and its practice present quite an example. Men most times react without reasoning and logic to matters of faith and religious affiliation. These reactions are even more shocking and bereft of reason when groups of believers are involved. It is therefore not surprising that believers of a particular faith can be called to join others in slaughtering "infidels" and the call is heeded with relish and an otherworldly kind of joy. Manipulation of group psychology is the most dangerous cause of intolerance between and among religious faiths. Karl Marx must have known the potentials of religion to be manipulated when he called for the abolition of religion which he saw as the halo of a vale of tears and the opium of the people (Wikipedia Opium, n.p.).

Looking at the place of religious conflicts in Nigeria, Yusufu Bala Usman saw them as mere manipulations in favor of the bourgeoisie and the disadvantage of the masses, who incidentally are the real worshippers. According to him, these are intrigues to bring disaffection between the exploited masses of different religious bodies—Muslims, Christians, traditionalists etc. (1987). As he puts it,

The real basis of the manipulation of religion in Nigeria today is the need to obscure from the people of Nigeria, a fundamental aspect of, that is, the domination of our political economy by a class of intermediaries who are being increasingly exposed. And this is to enable this class cover themselves with religious and ethnic disguises in order to further entrench division among our people, slow down their awakening, at any cost; even with the unity of the country for which so much has been sacrificed. (23)

Bala's point is that religious conflicts and whipping up sentiments against other religious faiths is a deliberate attempt at causing divisions among the oppressed class in society. This is a trick used by oppressors to divert attention from the injustices perpetrated against them. When bitterness is aroused against other faiths, the true enemy is obscured and the oppression can continue. Bala's point is well taken because most religious sentiments are especially expressed by the masses and deprived of society who vents their anger, hunger, and frustrations on other poor people while reacting to calls for intolerance and conflict from the high and mighty of their faith. Such acts of intolerance are sometimes means of settling political scores by the elites. Innocent adherents of some faiths may be called for war just to show political opponents how powerful a group of politicians they are. The present Boko Haram conflict smacks of this kind of manipulation.

(2) Illiteracy/ignorance: One of the greatest causes of religious intolerance and religion-orchestrated conflicts is illiteracy and ignorance. Karl Marx saw religion and religious temperaments as depriving man of 
his potentials since it makes man revolve around something else rather than himself. He sees man in this stage as ignorant, illiterate and not in control of himself and thus calls all men to reconsider their religious inclinations and drop the chains of faith from their necks (Wikipedia Opium, n.p.). This line of reasoning was also followed by Auguste Comte. Comte considered religion and the dependence of men on it as an act of ignorance and improper education. According to Lawhead, Comte sees man in the religious stage of life as being in infancy, for as a child attributes intentions and personality to his teddy bear, so people at this stage assumed that the cosmos is governed by the actions of personal gods. This stage developed from fetishism and animism through polytheism and culminated in monotheism (2002, 435). Comte may be right or wrong but he exposes the fact that religion and the religious fundamentalism has a way of depriving man of his humanity.

The way out of this is to have a proper education. A good education should liberate men from the shackles of religious orthodoxy because when people kill or maim others in the name of religion, it is an indication of ignorance and illiteracy. Furthermore, a good education should have the ability to free men's minds from religious sentiments and enable them to see a broader world-view. This world-view makes the properly educated to know that their beliefs are one out of the lot and this makes them to respect other people's opinions and religious affiliations. This kind of world-view was absent in the English society of Locke's days just as much as it is in present day Nigeria. It is therefore easy to recognize why both societies suffer(ed) the calamities of religious intolerance and crises emanating therefrom.

\section{John Locke on Religious Toleration}

John Locke was an English philosopher that lived between 1632-1704. Though educated as a physician, he developed his interest in philosophy generally and epistemology in particular. Like every other philosopher, he was also very interested in government, the society, and how it should function. As Dagobert Runes noted, Locke proved in his Letter on Toleration, the necessity of separating Church (religion) and State (1995, 722). The book is a unification of philosophy and religion. In it the bigotry and superstition of men are subdued by solid and irrefragable arguments. He opined that toleration is a word which is in general sacred to religion, and comprehends that liberty which one part of the community has to worship God according to their own views without any molestation from another. This, to him, is an inalienable right of every man since he is accountable only to God in matters of religion.

Locke first sought to make a difference between religious authority and civil authority. The former is said to belong exclusively to God while the latter belongs to the magistrate (civil leaders). This clarification is necessary to avoid governments and governors dabbling into the area of religion. He explains this more elaborately thus;

There are faults from which human affairs can perhaps scarce ever be perfectly freed, but yet such as nobody will bear the plain imputation of, without covering them with some special colour; and so pretend to commendation, whilst they are carried away by their own irregular passions. But however, that some may not colour their spirit of persecution and cruelty, with a pretence of care of the public weal and observation of the laws; and that others, under pretence of religion, may not seek impunity for their libertinism and licentiousness: in a word, that none may impose either upon himself or others, by pretences of loyalty and obedience to the prince, or of tenderness and sincerity in the worship of God; I esteem it above all things necessary to distinguish exactly the business of civil government from that of religion, and to settle the just bounds that lie between the one and the other. If this be not done, there can be no end put to the controversies that will be always arising between those that have or at least pretend to have, on the one side, a concernment for the interests of men's souls, and on the other side, a care of the commonwealth. (11) 
In the lengthy quotation above, Locke sets forth the first major requirement for curtailing religious conflicts. There is need to carefully separate religion from civil government so as to avoid the infiltration of the sentiments of the one into the other. Furthermore, this kind of separation will enable the government to treat matters like religious riots and crises as crimes rather than mere explosion of unavoidable sentiments. Locke's position must have provided the needed argument for the adoption of a secular structure by some states.

John Locke draws some implications from the separation advocated above. In the first place, the care of souls is not committed to the civil authority any more than to any man. What follows from this, according to Locke, is that God has not given any such authority to any man over another to compel any one to his religion (11). In the same vein such power cannot be vested in any authority by the consent of the people because no man can abandon the care of his own salvation to the choice of another, whether prince or subject to prescribe to him what faith or worship he shall embrace (12).

Secondly, Locke seeks to straighten out the fact that there cannot be any law that will bring anybody to the adherence of a particular faith without his consent. As he puts it, no man by nature is bound to any particular church or sect, but everyone joins himself voluntarily to that society in which, he believes, he has found that profession and worship which is truly acceptable to God (15). He goes ahead to assert that "if any man err from the right way, it is his own misfortune, no injury to thee; nor therefore art thou to punish in the things of this life, because thou supposes he will be miserable in that which is to come" (20).

Locke makes the worthy point that religious groups have no jurisdiction in worldly matters, nor are fire and sword any proper instruments wherewith to convince men's minds of error, and inform them of the truth (22). This is clearly an indictment on the method of using violence to propagate the message of any faith. As he puts it "the decision of that question belongs only to the supreme judge of all men, to whom also alone belongs the punishment of the erroneous" (22).

Still driving home the point that religion and faith cannot be forced on others he asserted that;

\begin{abstract}
Nobody, therefore, in sine, neither single persons nor churches (or mosques), nay, nor even commonwealths, have any just title to invade the civil rights and worldly goods of each other upon pretence of religion. Those that are of another opinion, would do well to consider with themselves how pernicious a seed of discord and war, how powerful a provocation to endless hatreds, rapines, and slaughters, they thereby furnish unto mankind. No peace and security, no not so much as common friendship, can ever be established or preserved amongst men, so long as this opinion prevails, "that dominion is founded in grace, and that religion is to be better propagated by arms”. (23-24)
\end{abstract}

From the foregoing, it is easy to see clearly the source of the religious crises that have threatened to engulf Nigeria. Some elements in some faiths have seen it as their right to bring their opinion to bear upon others without reservation and this they do with the utmost force. It is the resistance to this in most cases that brings an escalation of the violence. This is illustrated by Locke when he said that,

Now, as it is very difficult for men patiently to suffer themselves to be stript of the goods which they have got by their honest industry, and contrary to all the laws of equity, both human and divine, to be delivered up for a prey to other men's violence and rapine, especially when they are otherwise altogether blameless, and that the occasion for which they are thus treated does not at all belong to the jurisdiction of the magistrate (civil authority), but entirely to the conscience of every particular man, for the conduct of which he is accountable to God only: what else can be expected, but that these men growing weary of the evils under which they labour, should in the end think it lawful for them to resist force with force, and to defend their natural rights (which are not forfeitable upon account of religion) with arms as well as they can. (63-64) 
By the analogy of Locke, the effects of incessant attempts at forcing men to religions against their wishes are dire. He assumes that the effect is always violent as the oppressed will sooner or later seek to ward off the repression.

In summary, Locke advocates tolerance and toleration. According to him, it is reasonable and humane to allow each man to have his own religious experience and pursue same without fear of intimidation. He asserts that it is a natural right of every man to seek for God in the way that pleases him most or even to refrain from it without being bullied. When men are allowed to enjoy freedom of worship, it translates to peace in the community and the preservation of the human specie. Attempting to coerce men to a particular religion is wrongfully assuming the position of God and refusing to observe the obvious fact that religion is a matter of personal conviction which cannot be erased by the blows of swords or burning stakes.

\section{Problems With Locke's Idea of Religious Toleration}

Like every idea, Locke's position on religious toleration has some difficulties. In the first place, Locke's concept of religion seems looser than what obtains in and among Africans. Religion in the England of Locke's days could easily be detached from the individual practicing it hence the possibility of detaching it from other aspects of life. On the contrary, religion is what makes life worth living amongst the Africans. It is unthinkable to consider a religious African away from his faith.

Another difficulty with Locke's position is whether it can ever be possible to really separate between religion and civil government. Nominally people may say that they have no religious attachments but purging people of their religious affiliations is a tricky and extremely difficult thing to discern.

Locke's proposition also becomes problematic when we consider the close ties between most religions and the moral norms of societies. The norms of some societies are directly introduced by religions and sustained by their teachings. These norms are also the platforms upon which political ideals are built and sustained, hence separating state and religion would mean maiming the moral foundations of the society.

In spite of these however, Locke's solution to religious intolerance holds the key to reducing, if not completely ameliorating the monster of religious intolerance and conflict. The need for enlightenment about other people's religion is particularly useful in the fight against religious intolerance in Nigeria. Even though Locke's England was basically Christian, the sentiments that go with religion are basically same; hence Locke's solutions to religious intolerance can solve Nigeria's religious problems.

\section{Lessons for Nigeria from Locke's A Letter Concerning Toleration}

Present-day Nigeria is replete with religious conflicts that threaten to tear it asunder. In fact, most political misunderstandings find expression in the ignition and escalation of religious crises. A very fresh case is that of the post election violence in Kano and other states which followed the election victory of President Goodluck Jonathan in 2011 and was followed up with the Boko Haram insurgency that has claimed thousands of lives and is still counting. One of the demands of the insurgents is for Nigeria to drop its secular designation and be Islamized. This may sound political, but then the line between politics and religion is very thin in Nigeria. The reality of politicization of religion makes our attempt here to apply Locke's solution to religious crises in Nigeria more relevant.

We shall look at the lessons that Nigeria can learn from Locke from two perspectives viz: 
(1) Separation between government or secular affairs and religious affairs: Locke stated clearly that no group of people progresses well when there is no clear demarcation between religion and the administration of the state. When the administrators of the state that is "Magistrates" according to Locke are not properly separated from the practitioners of religion and when the practice of religion is not formally and clearly delineated, then there will be the possibility of some people using political offices for the pursuit of religious interests. Certain political office holders and law enforcement agents can use their positions to witch-hunt and victimize perceived opponents of their religious affiliations. This scenario is very commonplace in Nigeria. It is common knowledge that the military campaign against insurgency by the Boko Haram sect is proving tricky to prosecute because of the sabotage by religious bigots within the rank and file of the military and police. These bigots pretend to serve their country when their real allegiance is to their religion and so information is leaked to the insurgents thereby frustrating the campaign.

Apart from religious crises, the frustrating incursion of religion into public life in Nigeria is glaring in the sponsorship of mediocrity. It is common place to see and hear cases of people being deprived of what is due them as better educated or more intelligent people because they do not belong to one religious faith or the other. This smacks of injustice and oftentimes causes religious crises within the country. Where Locke's position is adopted, it is easy to ensure excellence and ameliorate crises that are anchored on feelings of injustice.

Locke's kind of separation may be difficult to achieve in states like Nigeria where there is more allegiance to religious and ethnic affiliations than to the state. Despite this difficulty however, the constitution should be clear about the separation between religious faiths and beliefs and secular affairs. This separation will enable the law to quickly and decisively handle crises that have religious underpinnings not as matters of faith that can be swept under the carpet, but as criminal offences.

Another way to ensure the separation that Locke talks about is to completely remove every religious element from secular national activities. Where there is a gathering of adherents of various religions, for instance, the national anthem can take the place of a prayer. This will forestall the misgivings that can erupt from feeling that one religion is superior or favoured over the other.

Furthermore, governments within Nigeria should be made to steer clear of involvement in matters pertaining to pilgrimage of Muslims or Christians to their holy lands. Pilgrimage to Mecca or Israel should not be sponsored by the government as this has a way of raising the conscious that the government will support all religious activities including those that are extremist and fanatical. Furthermore, it is wrong to aid the religions inclinations of the two major religions while pretending that adherents of other religions do not exist or do not matter. Money that belongs to the public should not be used in servicing a segment of people and exclude others. It is such meddling that makes it difficult to prosecute offenders of religious crises. I must however be quick to state that I am not advocating for the atheist creed that teaches that God is non-existent and not relevant (Lillback 65).

(2) Criminalization of religious fanaticism: One of the recommendations of Locke in his treatise on religious toleration is that the government should be detached from religion and its practice so that there can be room to bring bigots to justice and save society from the anguish of religious disturbances. This recommendation has special relevance for Nigeria. Most religious disturbances in Nigeria were followed by Panels of Enquiry into the remote and immediate causes of the crises with far reaching recommendations which were never implemented by the government. The reasons for the non-implementation of these recommendations are varied and complicated. Yet we cannot really overlook the possibility of the complicity of 
government officials in the stay of action on the recommendations. The need for the institution and enforcement of law against fanatics and fanaticism was well emphasized by Locke in the statement below:

It is the duty of the civil magistrate (governments), by the impartial execution of equal laws, to secure unto all the people in general, and to every one of his subjects in particular, the just possession of these things belonging to this life. If any one presume to violate the preservation of these things, his presumption is to be checked by the fear of punishment, consisting in the deprivation or diminution of those civil interests, or goods, which otherwise he might and ought to enjoy. (11)

Locke carefully puts in the hands of civil authorities the responsibility of giving security to the general population. This responsibility involves the punishment of those that assume that it is in their power to harm others for differences in opinion whether religious or otherwise. The profusion of religious crises in a particular political climate is an indication that the government in that place has failed in its basic obligation to its citizens.

(3) Deconscientization of religious fanatics and bigots: The major aim of Locke's A Letter Concerning Toleration is to remove from the consciousness of the average man the thinking that others must necessarily follow his religious convictions and beliefs. He wants all to understand that violence does not change the religious opinion of people but careful persuasion and reason can do wonders in winning people over to one's convictions. As he puts it,

But it is one thing to persuade, another to command:

One thing to press with arguments, another with penalties...every man has commission to admonish, exhort, and convince another of error; and by reasoning to draw him into truth...but penalties are no ways capable to produce such belief. It is only light and evidence that can work a change in men's opinions. And that can in no manner proceed from corporal sufferings, or any other outward penalties. (13)

With this knowledge that violence does not and cannot shape religious beliefs and opinion in mind, it is only necessary to adopt the approach of trying to decongest the minds of Nigerians in general and those who have the aim of forcing their faiths down the throats of others, however unpalatable they may be to them. Unless this mental decongestion is done, it will be difficult to stop religious crises in Nigeria.

\section{Conclusion}

It is not difficult to see that man is a religious animal. Evidences abound everywhere humans decide to stay. Faith therefore becomes an area of high priority. This has affected civilization in different ways, some in the positive and others in the negative. The case with Nigeria, which has occasioned this paper, is in the negative. It is the case that confusion and tension have arisen from inability of religious groups and faiths to cohere. The situation has made public life unbearable and proper government practically impossible. This has exposed the need for toleration among religious faiths in Nigeria. This need is partially filled by a careful study of how John Locke attempted to solve the religious problems of England of his days. Even though Locke's interest was on England of the 16th century, it is of interest to know that the reasons for religious fanaticism in his days are rather similar to those of present-day Nigeria. The psychology of fanatics and bigots of different climes are fundamentally same and so is their guiding logic which is terribly warped.

What we have done is a call to religious toleration. We have pointed to the fact that every man has a right, which is fundamental, to believe in whatsoever he chooses to. He may be wrong in his belief but this error can only be punished by God that takes the right to punish holders of erroneous beliefs from both individuals and 
the government. This truth and willingness to abide to it is all that is needed to the world in general and Nigeria in particular, of religious crises.

\section{Works Cited}

Asuo, Oduora, \& Ekpenyong, Obo. "The Philosophy and Method of Integrative Humanism and Religious Crises in Nigeria:

Picking Only the Essentials.” Sophia: An African Journal of Philosophy and Public Affairs 14.2 (April, 2014): 84-90.

Caner, Ergun, \& Caner, Emir. Unveiling Islam: An Insider's Look at Muslim Life and Beliefs. Kaduna: Evangel Publishers, 2002.

En.wikipedia.org. Opium of the People. Retrieved 4-5-2015.

---. Reigious Intolerance. Retrieved 4-5-2015.

Holmes, Arthur. Ethics: Approaching Moral Decisions. Illinois: IVP Academic, 2007.

Lawhead, William. The Voyage of Discovery: A Historical Introduction to Philosophy. Belmont: Wadsworth and Thomson Learning, 2002.

Lillback, Peter. Wall of Misconception: Does the Separation of Church and State Mean the Separation of God and Government? Pennsylvania: Providence Forum Press, 2007.

Locke, John. A Letter Concerning Toleration. London: Huddersfield, 1796.

Mbiti, John. African Religions and Philosophy. London: Heinemann, 1997.

Runes, Dagobert. Treasury of Philosophy. New York: Philosophical Library, 1995.

Usman, Bala. The Manipulation of Religion in Nigeria: 1977-1987. Kaduna: Vanguard Printers, 1987. 